\title{
Influence of omentoplasty on colonic anastomosis in animals submitted to hemorrhagic shock in rats ${ }^{1}$
}

\author{
Influência da omentoplastia na anastomose cólica de animais submetidos a choque hemorrágico \\ em ratos
}

\author{
Ricardo Bolzam-Nascimento ${ }^{\mathrm{I}}$, Cláudio Saddy Rodrigues Coy ${ }^{\mathrm{VI}}$, Yara Ematné Amaral Pereira ${ }^{\mathrm{I}}$, Raquel Franco Leal', Rosana \\ Celestina Morandin Reis ${ }^{I I}$, Mário Mantovani"II, Maria de Lourdes Setsuko Ayrizono ${ }^{\mathrm{IV}}$, Wu Feng Chung ${ }^{\mathrm{V}}$, João José Fagundes ${ }^{\mathrm{VII}}$ \\ ${ }^{I}$ Master, Postgraduate Program in Surgery, UNICAMP, Sao Paulo, Brazil. \\ ${ }^{\text {II }} \mathrm{PhD}$, Biologist, Trauma Surgery Investigation Laboratory, UNICAMP, Sao Paulo, Brazil. \\ III PhD, Full Professor, Trauma Surgery, Surgery Department, UNICAMP, Sao Paulo, Brazil. \\ Iv $\mathrm{PhD}$, Assistant Professor, Digestive Tract Diseases, Surgery Department, UNICAMP, Sao Paulo, Brazil \\ v PhD, Researcher Professor of Surgery Department, UNICAMP, Sao Paulo, Brazil. Bioinformatics Laboratory Coordinator, UNIOESTE, Foz do \\ Iguaçu, PR, Brazil.

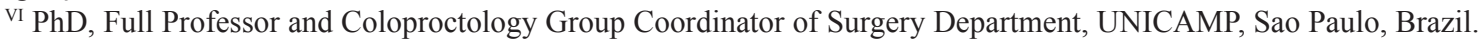 \\ ${ }^{\mathrm{VII}} \mathrm{PhD}$, Full Professor, Coloproctology Group of Surgery Department, UNICAMP, Sao Paulo, Brazil.
}

\begin{abstract}
Purpose: To analyze influence of omentoplasty on anastomosis in descending colon of rats. Rats were submitted to the hypovolemic shock of the hemorrhagic type by the Biomechanical Test of Pressure of Rupture by Liquid Distension (BTPRLD). In addition, establish a type of acute anemia in rats that are provided to the study. Methods: Comparative study between two groups of animals with ten rats in each one, all submitted to hemorrhagic shock for 30\% volemic removal by the carotid artery. An anastomosis was performed in left colon. An anastomosis was performed in the left colon. Group 1 took place anastomosis with Polyvinyl Chloride (P.V.C) film to prevent the adhesions formation on sature line. Group 2 placed the great omentum around the anastomosis. Euthanasia occurred on the fifth day, when the anastomoses were submitted to the biomechanical test of pressure of rupture by liquid distension (BTPRLD). Results: High rupture pressure was gained with omentoplasty group in relation to the group in which anastomosis was protected from adhesions formation. A statistical significance was noted. Conclusion: Protection by great omentum has increased the anastomosis resistance of the shocked animals. Also, the proposed hemorrhagic shock type has proven to be useful for this study.
\end{abstract}

Key words: Anastomosis, Surgical. Colon. Omentum. Rats.

\section{RESUMO}

Objetivo: Analisar a influência da omentoplastia sobre anastomose realizada em cólon descendente de ratos que foram submetidos a choque hipovolêmico do tipo hemorrágico, por meio do Teste Biomecânico de Pressão de Ruptura à Distensão por Líquido. Além disso, estabelecer modelo de anemia aguda em rato que se preste ao referido estudo. Métodos: Estudo comparativo entre dois grupos de animais com 10 ratos em cada, todos submetidos a choque hemorrágico por retirada volêmica de $30 \%$ através da artéria carótida, sendo realizada anastomose em cólon esquerdo. No grupo 1 realizou-se proteção da anastomose com película de polivinilcloreto para impedir a formação de aderências sobre a linha de sutura; no grupo 2 colocou-se em torno da anastomose o grande omento. A eutanásia deu-se no quinto dia, quando as anastomoses foram submetidas ao Teste Biomecânico Pressão de Ruptura à Distensão por Líquido (TBPRDL). Resultados: Obteve-se maior pressão de ruptura no grupo em que se realizou a omentoplastia em relação ao grupo em que a anastomose foi protegida da formação de aderências, notando-se significância estatística. Conclusão: A proteção pelo grande omento aumentou a resistência das anastomoses dos animais chocados. Também, o modelo de choque hemorrágico proposto mostrou-se útil para este estudo.

Descritores: Anastomose Cirúrgica. Colo. Omento. Ratos.

${ }^{1}$ Research performed at the Division of Experimental Surgery, Department of Surgery, Campinas University (UNICAMP), Sao Paulo, Brazil. 


\section{Introduction}

The healing is intersection point between all the surgical specialties. Regarding the intestinal healing, it is well known devastating consequences of suture dehiscence which always causes a high social psychological and economic price. Anastomotic strain rates in colorectal surgery still are nothing to be avoided. It is possible to go from zero to $69 \%$. This is the responsibility to be investigated, since in many cases it does not occurs clinical events $^{1}$. Currently it is more common dehiscence of colorectal anastomosis, clinically manifested that has not reached $10 \%{ }^{2}$. For others, the anastomosis failure is still at higher levels of 10 to $20 \%{ }^{3,4,5}$. In any case, mortality in the large intestine surgery remains between 2 to $4 \%$ due mainly to anastomotic failures ${ }^{6}$. Higher rates of anastomotic complications are expected when sutures in adverse conditions were performed. Several of these protection conditions and factors were also studied and used as anti-hormonal and not hormonal anti inflammatory ${ }^{7,8}$, immunosuppressive drugs ${ }^{7}$, hormonies ${ }^{9}$, antibiotics ${ }^{10}$, antioxidants ${ }^{11}$, short chain fatty acids action ${ }^{12}$, sepsis ${ }^{13}$; peritonitis ${ }^{13}$, $\operatorname{trauma}^{14}$, diabetes ${ }^{15}$, hyperbaric hyperoxygenation ${ }^{16}$, pentoxiphiline ${ }^{4}$. Advanced age, uremia, cirrhosis, cancer in advanced stage, anemia and malnutrition are factors very feared.

Blood perfusion found deficient in ischemia and ischemiareperfusion syndrome is a cause of failure in the intestinal anastomoses healing $4,17,18,19$

An acute anemia trial has taken on a continuing basis histological and biochemical damage to the region of colic anastomoses. As increased presence of inflammatory infiltrate the acute phase decreased deposition of collagen fibers and hydroxyproline $\mathrm{e}^{6,12}$. Lauand et al. ${ }^{20}$ with $40 \%$ bleeding there was also found no change of hydroxyproline, although there were still histological findings that are theoretically harmful to healing. Baffa et al. ${ }^{21}$ despite histological changes found, does not verify decrease of hydroxyproline. In this work, acute anemia was produced by $30 \%$ volemia removal. As for the mechanical strength of colic anastomoses in these hemorrhagic shock type results does not show uniformity, pressure of an explosion cannot be changed ${ }^{12}$ or only do so in the $14^{\text {th }}$ day $^{6}$.

Adhesions directly around the anastomosis, with the great omentum, has used for a long time as protection for sutures $^{18,19,22,23,24,25,26}$. However, controversy still on the practical results of this method.

With increasing frequency the intestinal anastomosis is performed in acute anemia due to trauma or excessive intraoperative bleeding. For the sature line hypo perfusion will be added to other adverse factors such as lesions to another organs, infection, hypothermia, acidosis, systemic inflammatory response and increasing collapsing organic risks to the anastomosis. These facts justify investigations in order to minimize the aggravation of anastomosis in patients already critical.

\section{Methods}

This work was approved by the Committee of Ethics and Animal Experiments of the Campinas State University, according to the ethical principles adopted by the Brazilian College of Animal (COBEA).

For the animal experiment, a rat was used (Rattus norvegicus albinus, Rodentia Mammalia). A male of the Wistar line, weight ranging from 359 and 304 grams and approximately age of 90 days. It was raised under similar environmental conditions at the Central vivarium Biotery of the UNICAMP (CEMIB / UNICAMP).

Two groups were formed with 10 experimental animals that were shocked in each group. In vigency of hemorrhagic shock anastomosis was performed in the left colon of each rat. Group 1, the anastomosis was evolved by a polyvinyl chloride film (PVC) with the aim of preventing of adhesions forming on the suture line, which could interfere with the results. In group 2, took place on the circumferential omentoplasty anastomosis. Euthanasia was performed on the fifth day after submitting to test each anastomosis biomechanical of pressure of rupture (BTPRLD. Animals that led to death was excluded, and those had anastomosis dehiscence of euthanasia was replaced.

For anesthesia the sodium pentobarbital was used with three percent (Hypnol-Fontoveter) administrated by the caudal vein. The dose used was 60 milligrams per kilogram of weight.

To obtain the shock, aseptic technique was used. The right carotid artery was dissected and catheterized with polyethylene tube (PE40), previously heparinized to cause bleeding. This was done by the removal of 0.5 milliliters of blood every two minute. It was interrupted when it got average levels of mean arterial pressure (MAP) equal to $50 \mathrm{mmHg}$ or as removal represented $30 \%$ estimated volemia for the animal. To provide the model and to increase the survival of animals restoration of one-third of the removed volume in the physiological saline solution form. The volume assessment of each animal was calculated to $5.43 \%$ by animal weight ${ }^{27}$.

As a shock marker and tissue ischemic the serum lactate were used and measured through lactometer. Three measures were performed: first at the start of surgery before the start of the volemic removal. Secondly, 15 minute after the last removal and the establishment of shock. Last condition after the surgery with the abdomen closed. Result was shown in millimoles per liter $(\mathrm{mmol} / \mathrm{l})$. To maintain the temperature of the animal a heated mattress was used and calibrated to remain around 38 and 40 degrees centigrade to avoid hypothermia. MAP was controlled at all times with digital recorder-manometer.

After middle laparotomy the left colon was cut to three centimeters of peritoneal reflection and the anastomosis. This was performed with separate points in the unique seromuscular plan with polypropylene wire. After that in Group 1 polyvinyl chloride film is placed on the anastomosis and group 2 omentoplasty perianastomotic is performed. The building of these structures was made by the same polypropylene wire. The PVC film was obtained from the bag containing the serum.

On the fifth postoperative day, euthanasia was performed with a lethal dose of 3\% sodium thiopental which was applied through caudal vein.

For the biomechanical test, a colic segment was eliminated of four centimeters containing anastomosis in their average region, equidistant from extremes. The handle underwent careful cleaning of the lumen with saline solution and placed in a receptacle of saline solution and hydrochloride papaverine in concentration levels of 250 milligrams per liter. These were kept at a temperature of 37 degrees centigrade for a period of 20 minutes. It was intended to minimize the variability of muscle contractions arising from the manipulation ${ }^{28}$. 
The quality assessment of anastomoses was performed by biomechanical test of pressure of rupture by liquid distension which was defined as intraluminar pressure, recorded by polygraph, necessary to promote the overflow of the solution infused by anastomotic line.

The system mounting for measuring the BTPRLD has previously been described and will be summarized here ${ }^{16,18,19}$. After eliminated the surgical piece of papaverine solution a cannon catheter No. 18 of "Teflon" was introduced in their extremities. These in turn were attached to the 3-way triple flow tap and connected to the glass syringes previously positioned in two infusion pumps. One of them served to introduce saline solution within the handle through one end. The other provided only as a support for sustaining the other end of the tester. After mounting that system one of the taps was connected to the pressure transmitter of the polygraph through polyethylene catheter Thus saline solution was injected through the plastic syringe connected to the polygraph pressure transmitter forming a net column providing system zero. The explosion pressure study was introduced by the infusion of saline solution in two milliliters per minute speed. Then it was interrupted after a rapid fall observation in the register of the pressure curve of the polygraph. It was noted that the value in mercury millimeters from the maximum pressure was responsible for the handle breaking (Figure 1).

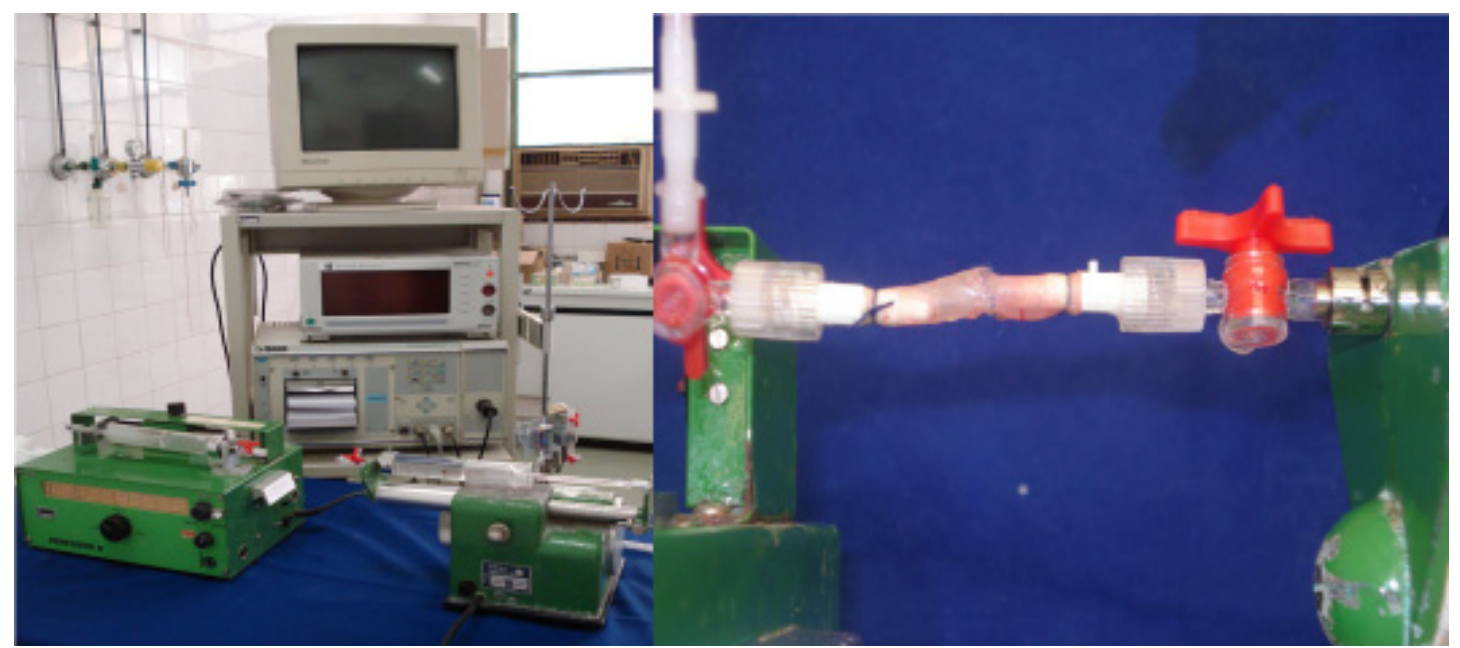

FIGURE 1 - On the left showing the pressure balance system with the presence of an infusion pump and other support; on the right showing the catheters with both ends introduced in light of intestinal segment containing the anastomotic line at the centre

For statistical analysis the Mann-Whitney's nonparametric test, variance analysis (Anova) Tukey test and Spearman's correlation coefficient and contrast was used. 5\% significance level was used ( $p$-valor $\leq 0,05)$.

\section{Results}

To achieve ten animals in control group 1, there was needed to test forty six rats. Of these seventeen died (36.9\%). The deaths often occurred in the immediate postoperative period and signs of evidence of respiratory failure were noted. Another nineteen animals $(41.3 \%)$ although they came lively on the fifth day, presented anastomotic dehiscence to euthanasia and were regarded as not assessable for BTPRLD. Ten rats remaining (21.8\%) showed their integration anastomoses on the fifth day and were regarded suitable for testing. Group 2, shock and anastomosis affected by omentum were formed with seventeen animals. Of these, seven (41.1\%) progressed to the death almost always in the immediate postoperative period and with evidence of respiratory failure. Ten rats surviving $(58.9 \%)$ presented intact anastomoses on the fifth day. When the realization of euthanasia being considered assessable for BTPRLD. There was not verified sature dehiscence on surviving animals.

The following animals died or had anastomotic dehiscence will be not considered. The following animals died or had anastomotic dehiscence will be not considered. Twenty animals assessed will be shown only. Ten of each group was submitted to biomechanical testing. Items will be analyzed: Removal of blood volume, surgical time, mean arterial pressure, lactacidemia, weight loss and BTPRLD results.

\section{Removal blood volume}

Twenty animals were considered assessable its volemia was estimated from $16.5 \mathrm{ml}$ to $18.9 \mathrm{ml}$ (average of $17.8 \mathrm{ml}$ ). Ten rats in Group 1 had their volume estimated at between 16.5 and $18.9 \mathrm{ml} \mathrm{ml}$ (average of $17.53 \mathrm{ml}$ ). For ten animals of Group 2 the estimated volume ranged from 16.9 to $19.4 \mathrm{ml} \mathrm{ml}$ (average of 18.06 $\mathrm{ml}$ ). For statistical analysis, there is no noted significant difference between the volumes. For statistical analysis no noted significant difference between the volemias estimated for the two groups in compliance with a $\mathrm{p}$-value $=0.1284$ when applied to the MannWhitney test.

The removed volume ranged from $4.5 \mathrm{ml}$ to $6.0 \mathrm{ml}$ (average of $5.67 \mathrm{ml}$ ). For Group 1, the removal volumes ranged from $4.5 \mathrm{ml}$ to $6.0 \mathrm{ml}$ (average of $5.4 \mathrm{ml}$ ). In percentages removal amounted from $26.3 \%$ to $34.6 \%$ (average of $30.9 \%$ ). For Group 2 the removal pf blood was from $4.5 \mathrm{ml}$ to $5.7 \mathrm{ml}$ (average of $5.3 \mathrm{ml}$ ). In percentages the removal amounted from $25.0 \%$ to $32.3 \%$ (average of $29.5 \%$ ). 
Comparative statistical analysis showed no significant difference in the removal volume $(p=0.58)$ either as the percentage of the removal volume between the groups $(p=0.25)$ when applied to the Mann-Whitney statistical test.

\section{Surgical time}

The surgical time in group 1 ranged between 40 and 97 minutes with an average of 64 minutes and average of 57 minutes. In group 2 times ranged between 30 and 60 minutes, averaging 47.1 minutes and an average of 57 minutes. There was no statistical difference between the operative time of the two groups, according to statistical analysis by the Mann-Whitney method with $\mathrm{p}=0.1602$.

\section{Mean arterial pressure}

MAP was measured before the bleeding and 15 minutes after receiving the shock at the end of the experiment, with the abdomen already closed. The initial MAP for animals of Group 1 ranged from 103 to $117 \mathrm{mmHg}$ (average of 107.9). At 15 minutes the range was from 48 to $75 \mathrm{mmHg}$ (average of 54.8). The end MAP ranged from 64 to $100 \mathrm{mmHg}$ (average of 84.2). In Group 2 the initial WFP ranged from 91 to $129 \mathrm{mmHg}$ (average of 109.7). Measurements of 15 minutes ranged from 48 to $77 \mathrm{mmHg}$ (average of 54.6). The end MAP on the same group was 60 to $102 \mathrm{mmHg}$ (average of 81.5). Statistical analysis showed no significant difference between groups in the three areas of the measurement as applied to the variance analysis (ANOVA). That is, initial MAP was Similar in both groups as well as 15 minutes after-shock and at the end of the experiment. However, it was different with statistical significance from one measurement to the other within each group $(p=0.0001)$.

\section{Lactate}

Initial lactate for Group 1 ranged from 1.5 to $2.7 \mathrm{mmol} / 1$ (average of 2.1). At 15 minutes for the same group, it was 1.7 to 3.8 (average of 2.7). The final measurement ranged from 2 to 4.9 $\mathrm{mmol} / \mathrm{l}$ (average of 3.3). For the Group 2, initial lactate ranged from 1.6 to $3.1 \mathrm{mmol} / \mathrm{l}$ (average of 2.2). At the 15 minute measure oscillation was 1.5 to $4 \mathrm{mmol} / \mathrm{l}$ (average of 2.9). For end lactate, the range was from 2.8 to $5.8 \mathrm{mmol} / \mathrm{l}$ (average of 3.6). Statistical analysis showed no significant difference between groups in the three moments of the measurement of serum lactate, as applied the variance analysis (ANOVA). However, there was significance between each time within each group $(p=0,0001)$.

\section{Weight loss}

Animals were weighed at the beginning of the test and at the time of euthanasia. In Group 1, initial weight ranged from 304 to $349 \mathrm{~g}$ (average of 322.7). The final weight in the same group was 252.2 to 310.7 grams (average of 272.6). The weight loss ranged from 11.8 to 66.8 grams (average of 50.1). In percentages the oscillation was 3.7 to $21.1 \%$ (average of 15.5 ). For the Group 2 the initial weight ranged from $318 \mathrm{~g}$ to $359 \mathrm{~g}$ (average of 333.2 grams). The final weight ranged from 268 to 310.2 grams (average of 288.4). Weight loss occurred ranged from 18.4 to 76.2 grams (average of 44.7). Percentages ranged from 8.2 to $21.3 \%$ (average of 13.9). Statistically two groups using the Mann-Whitney test were compared and a p-value of 0.3073 resulted showing that there was no significance in relation to ponderal loss between the groups.

\section{distension}

\section{Biomechanical test of pressure of rupture by liquid}

In all tested animals both groups ruptures occurred in the suture line and always on an edge against mesenterial. Groups were compared by the Mann-Whitney statistical method, a $p=0.0509$ was presented showing statistical significance. In Table 1 there are values found, measured in millimeters of mercury ( $\mathrm{mm} \mathrm{Hg}$ ).

TABLE 1 - Rupture pressure by liquid distension in Groups 1 and 2 on the fifth day after surgery

\begin{tabular}{c|c|c|c}
\hline Group 1 & Explosion Pressure & Group 2 & Explosion Pressure \\
\hline 1 & 77 & 1 & 229 \\
\hline 2 & 142 & 2 & 169 \\
\hline 3 & 152 & 3 & 135 \\
\hline 4 & 94 & 4 & 195 \\
\hline 5 & 119 & 5 & 154 \\
\hline 6 & 175 & 6 & 148 \\
\hline 7 & 129 & 7 & 191 \\
\hline 8 & 75 & 8 & 189 \\
\hline 9 & 165 & 9 & 144 \\
\hline 10 & 158 & 10 & 106 \\
\hline Average & $\mathbf{1 2 8 . 6} \mathbf{~ m m H g}$ & Average & $\mathbf{1 6 6 \mathbf { m m H g }}$ \\
\hline
\end{tabular}




\section{Discussion}

The intestinal anastomoses are performed ever more frequently in patients with adverse conditions for healing. Such as immunosuppression, infection, local ischemia, uremia, malnutrition, anemia, advanced age, and other. Secondary shock to bleeding is taken as one of the main conditions of adversity. Experimentally, it is capable of causing in the intestinal wall biochemistry ${ }^{29}$, histological ${ }^{30}$ and prolonged mechanical-structural changes $^{30}$. Experimentally may still predispose to worsen intestinal anastomoses healing ${ }^{6,12,20,30}$.

In order to prevent the anastomotic dehiscence or minimize its consequences can be realized in the circumferential direction of adhesions on a suture line with the great omentum. A double protection both mechanical and biological is obtained. From a mechanical point of view is expected that this structure seal micro- failure and dehiscence suture. A biological mode, besides the additional blood irrigation to irrigation to the anastomosis, omentum can absorb necrotic remains helping to unbridle and promote better granulation along the suture line ${ }^{31}$.

In this study an animal model of hemorrhagic shock was obtained which was performed in a colic anastomosis protected or not by omentum. It was tested after five days by biomechanical test of pressure of rupture by liquid distension (BTPRLD).

The fifth day was chosen to represent a postoperative phase where sature points have lost its maximum power of sustentation and fibroplasia period and collagen deposits are not quantitatively significant yet ${ }^{32}$.

The amount of removal blood from each animal was around $30 \%$ of volume. With that there was acute anemia of at least moderate severity, Class II to III, is considered in humans. Volume restoration was made so in part about a third from removal in saline solution form and only after abdomen is closed. After the pilot studies came to that form of standardization of work; there was a shock type that can be considered severe. Mortality rate was $38 \%$ which characterizes the models impact. Moreover, the survival of $62 \%$ cannot be regarded as small and a reasonable number of animals were provided to carry out the work. Because the model had produced anastomotic dehiscence performed $30.1 \%$. It also lends itself to the study of intestinal healing in this adverse condition, with other types of methodological approach. Statistical analyses performed basically adopted comparisons between the two groups that they would be equal and came to the same conditions until the moment when they were submitted to BTPRLD. This passed the same experimental conditions to have the anastomoses tested as to its quality, were the main goal of this study. Two groups were Similar with respect to surgical time, removal of blood volume lactate, MAP and weight loss. They differed on the suture line resistance only.

The results verified by BTPRLD could not be compared with similar work on that experienced colic anastomoses and hypovolemic shock. This is because it was not found work to study protection anastomotic omental in a shocked animal model. In this study there was a benefit to the group of animals under conditions of shock when their anastomoses were protected by the omentum. This conclusion can be inferred by two different points of the experiment: the post-operative development, lack of dehiscence in Group 2 and the BTPRLD. The biomechanical testing showed that the animals used in the experimental group had anastomoses more resistant than those in the group without directed adhesions. This had statistical significance.

Regarding the deaths that occurred inferences cannot be made if it had a direct relation with omental protection because the deaths were early. It is much more probable were due to the hemorrhagic shock effects than anastomotic complications. In the experiment the anastomoses were tested after the removal of PVC film in the control group and the omental wrapping in the group with adhesions. The adhesions were eliminated in the most delicate possible way. However, is certain that were imposed micro trauma to healing by the tip of the contour scissors. This fact may have caused some degree of reduction of resistance measured by the BTPRLD. If the same test had been done without this removal, and it had tested the monoblock anastomosis and circumferential adhesions resistance, it is true that it would have gained higher pressures of a collapse, further increasing the statistical significance, which was the limit. This simulation shows more of what happens "in vivo".

\section{Conclusions}

1- Use of Hemorrhagic shock type proved to be useful to study of the healing of anastomoses subjects to conditions of adversity;

2- Protection of the great omentum increased anastomoses resistance.

\section{References}

1- Goligher JC, Grahan NG, DeDombal FT. Anastomotic dehiscence after anterior ressection of the rectum and sigmoid. Br J Surg. 1970;57:109-18. 2- Corman ML. Principles of surgical technique in the treatment of carcinoma of the large bowel. World J Surg. 1991;15:592-6.

3- Schiedeck TH, Schwandner O, Baca I, Baehrlehner E, Konradt J, Köckerling F, Kuthe A, Buerk C, Herold A, Bruch HP. Laparoscopic surgery for the cure of colorectal cancer. Dis Colon Rectum. 2000;43:1-8.

4- Membrives PP, Ruiz-Luque V, Escudero-Severín C, Aguilar-Luque J, Méndez-García V. Effect of pentoxilyne on healing of ischemic colorectal anastomoses. Dis Colon Rectum. 2006;50:369-75.

5- Nesbakken A, Nygaard K, Lunde OC. Outcome and late functional results after anastomotic leakage following mesorectal excision for rectal cancer. Br J Surg. 2001;88:400-4.

6- Buchmiller-Chair TL, Kim CS, Won NH. Effect of acute anemia on the healing of intestinal anastomoses in the rabbit. J Trauma. 2001;51:363-8. 7- Mantovani M, Leonardi LS, Alcântara FG, Hadler WA. Estudo comparativo entre suturas em um e dois planos no intestino delgado na vigência de drogas imunossupressoras: trabalho experimental no cão. Rev Paul Med. 1977;89:35-41.

8- Souza JB, Soares EG, Aprilli F. Effect of diclofenac sodium on intestinal anastomotic healing: experimental study on the small intestine of rabbits. Dis Colon Rectum. 1991; 34:13-7.

9- Yarimkaya A, Apaydin B, Unal E, Karabicak I, Aydogan F, Uslu E, Erginoz E, Artis T, Eyuboglu E. Effects of recombinant human growth hormone and nandrolone phenylpropionate on the healing of ischemic colon anastomosis in rats. Dis Colon Rectum. 2003;46:1690-7.

10- Hershey SD, Lucas CE, Ledgerwood AM, Cushing R. Effects of antimicrobials on wound healing. Surg Forum. 1987;33:30-1.

11- Garcia GG, Criado FJG, Persona MAB, Alonso AG. Healing of colonic ischemic anastomoses in the rat: role of superoxide radicals. Dis Colon Rectum. 1998;41:892-5. 
12- Greca FH, Biondo-Simões MLP, Paula JB, Noronha L, Cunha LSF, Baggio PV. Correlação entre o fluxo sangüíneo intestinal e a cicatrização de anastomoses colônicas: estudo experimental em cães. Acta Cir Bras. 2000;15:88-94.

13- Biondo-Simões MLP, Greca FH, Ioshi S, Menini CM, Tawil IIET, Chin EWKC, Stahalschmidt FL, Sperandio CA, Cebrian CFM. Influência do tempo transcorrido entre a lesão do cólon e a síntese no processo de cicatrização. Acta Cir Bras. 2000;15:24-9.

14- Irvin TT, Hunt TK. The effect of trauma on colonic healing. Br J Surg. 1974;61:430-6.

15- Goodson WH, Hunt TK. Wound healing in experimental diabetes mellitus: importance of early insulin therapy. Surg Forum. 1978;29:95-8.

16- Rocha AA, Coy CSR, Góes JRN, Ayrizono MLS, ChungWF, Fagundes JJ. Comparative study of the hyperbaric hyperoxigenation in isquemic colonic loops in rats. Acta Cir Bras. 2007;22:85-91.

17- Mantovani M, Leonardi LS, Alcântara FG, Hadler WA. Estudo comparativo entre suturas em plano único e em dois planos no intestino delgado na vigência de isquemia: trabalho experimental no cão. Rev Paul Med. 1976;87:56-63.

18- Chung WF, Ayrizono ML, Fagundes JJ, Coy CSR, Góes JRN, Leonardi LS. Estudos biomecânicos da ação de aderências sobre anastomose cólica. Trabalho experimental em ratos. Acta Cir Bras. 2003;18:216-33.

19- Mochizuki M, Chung WF, Coy CS, Ayrizono ML, Góes JR, Fagundes JJ. Effect of guided adhesions on ischemic colic anastomoses in rats. Acta Cir Bras. 2005;20:247-52.

20- Lauand F, Féres O, Rocha JJR, Campos AD, Carvalho FG. Efeito da hipovolemia sobre a cicatrização de anastomoses colônicas. Estudo experimental em ratos. Rev Bras Coloproctol. 2004;24:317-21.

21- Baffa LP, Garcia RLS, Campos AD, Rocha JJR, Feres O. Efeito da anemia aguda na cicatrização de anastomoses colônicas. Estudo experimental em ratos. Rev Bras Coloproctol. 2005;25:24-30.
22- Ellis H. The etiology of post-operative abdominal adhesions. An experimental study. Br J Surg. 1962;50:10-6.

23- Merad F, Hay JM, Fingerhut A, Flamant Y, Molkhou JM, Laborde Y. Omentoplasty in the prevention of anastomotic leakage after colonic or rectal resection: a prospective randomized study in 712 patients. French Associations for Surgical Research. Ann Surg. 1998;227:179-86.

24- Greca FH, Biondo-Simões MLP, Souza Filho ZA, Silva APG, Nassif AE, Burda-Costa P. Ação do omento na cicatrização de anastomoses colônicas. Estudo experimental em ratos. Acta Cir Bras. 1998;13(3):172-6. 25- O'Leary DP. Use of the greater omentum in colorectal surgery. Dis Colon Rectum. 1999;42:533-9.

26- Agnifili A, Schietroma M, Carloni A, Mattucci S, Caterino G, Carlei F, Lygidakis NJ, Carlei F. The value of omentoplasty in protecting colorectal anastomosis from leakage. A prospective randomized study in 126 patients. Hepatogastroenterology. 2004;51:1694-7.

27- Bivin WS, Crawford MP, Brewer NR. Morphophysiology. In: Baker HJ, Lindsey JR, Weisbroth SH. The laboratory rat. Biology and disease. Academic Press Inc.: Londres; 1979. p.73-103.

28- Naresse LE. Efeito da peritonite fecal na cicatrização do cólon distal no rato. Avaliação anátomo-patológica, estudo da força de ruptura e da hidroxiprolina tecidual [Tese - Doutorado]. Botucatu: Universidade Estadual Paulista; 1990.

29- Dzienis-Koronkiewicz E, Debek W, Chyczewski L. Hemorrhagic shock-induced changes in the cathepsin D activity in the intestinal wall and blood serum in rats. Eur J Pediatr Surg. 1998;8:288-94.

30- Brito MV, Koh IH, Lamarão LG, Damous SH. Effect of hypovolemic shock in anastomose of small intestine of rats. Arq Gastroenterol. 2001;38:116-24. 31- Ruffini E. Surgical aplications of the greater omentum: a critical review of the literature. Panminerva Med. 1992;34:135-40.

32- Hogstron H. Mechanics and prevention of decrease in wound margin strengh. Acta Chir Scand. 1987;539:1-63.

Conflict of interest: none Financial source: none

\title{
Correspondence:
}

Ricardo Bolzam-Nascimento

Rua Baia, 884

13480-520 Limeira - SP Brazil

Phone: (55 19)8101-5537/3446-1412

ricardobolzam@yahoo.com.br

Received: October 28, 2008

Review: December 22, 2008

Accepted: January 28, 2009

\author{
How to cite this article \\ Bolzam-Nascimento R, Coy CSR, Pereira YEA, Leal RF, Reis RCM, Mantovani M, Ayrizono MLS, Chung WF, Fagundes JJ. Influence \\ of omentoplasty on colonic anastomosis in animals submitted to hemorrhagic shock in rats. Acta Cir Bras. [serial on the Internet] 2009 \\ Mar-Apr;24(2). Available from URL: http://www.scielo.br/acb
}

*Color figures available from www.scielo.br/acb 